\title{
PANI-Ag-Cu Nanocomposite Thin Films Based Impedimetric Microbial Sensor for Detection of $\boldsymbol{E}$. coli Bacteria
}

\author{
Huda Abdullah, ${ }^{1}$ Norshafadzila Mohammad Naim, ${ }^{1}$ \\ Noor Azwen Noor Azmy, ${ }^{1}$ and Aidil Abdul Hamid ${ }^{2}$ \\ ${ }^{1}$ Department of Electrical, Electronic, and System Engineering, Faculty of Engineering and Built Environment, \\ Universiti Kebangsaan Malaysia, 43650 Bangi, Malaysia \\ ${ }^{2}$ School of Biosciences and Biotechnology, Faculty of Science and Technology, Universiti Kebangsaan Malaysia, \\ 43650 Bangi, Malaysia \\ Correspondence should be addressed to Huda Abdullah; huda@eng.ukm.my
}

Received 30 May 2014; Accepted 1 August 2014; Published 15 October 2014

Academic Editor: Lavinia Balan

Copyright (c) 2014 Huda Abdullah et al. This is an open access article distributed under the Creative Commons Attribution License, which permits unrestricted use, distribution, and reproduction in any medium, provided the original work is properly cited.

PANI-Ag-Cu nanocomposite thin films were prepared by sol-gel method and deposited on the glass substrate using spin coating technique. Polyaniline was synthesized by chemical oxidative polymerization of aniline monomer in the presence of nitric acid. The films were characterized using XRD, FTIR, and UV-Visible spectroscopy. The performance of the sensor was conducted using electrochemical impedance spectroscopy to obtain the change in impedance of the sensor film before and after incubation with $E$. coli bacteria in water. The peaks in XRD pattern confirm the presence of $\mathrm{Ag}$ and $\mathrm{Cu}$ nanoparticles in face-centered cubic structure. FTIR analysis shows the stretching of $\mathrm{N}-\mathrm{H}$ in the polyaniline structure. The absorption band from UV-Visible spectroscopy shows high peaks between $400 \mathrm{~nm}$ and $500 \mathrm{~nm}$ which indicate the presence of $\mathrm{Ag}$ and $\mathrm{Cu}$ nanoparticles, respectively. Impedance analysis indicates that the change in impedance of the films decreases with the presence of $E$. coli. The sensitivity on $E$. coli increases for the sample with high concentration of $\mathrm{Cu}$.

\section{Introduction}

Conducting polymers are the new material and they are rapidly emerging by making the scientific and technological interest increasingly growing. This kind of polymers has already been found for extensive application in electrochemical sensors, due to their electroactivity, compatibility with biological molecules, environmental stability, and ease of synthesis from inexpensive monomers. Among the available intrinsically conducting polymers, polyaniline (PANI) is found to be the most promising because of its easy synthesis, low cost monomer, tunable properties, high conductivity, and better stability compared to others. Microbial detectors which are made from such organic polymer can help in identification of the microbes quickly and easily. For current technology, polymeric sensors are the suitable ones for fabrication of microorganisms monitors.
The conductivity of this conducting polymer can be controlled by the process of doping which may be carried out through a chemical, electrochemical, or photochemical route [1]. The conductivity is characterized by charge transfer from dopant to polymer or from polymer to dopant [2]. The interaction between polyaniline and noble metals has attracted a great deal of interest in a wide variety of applications. The composite of polyaniline with metals has been widely used in many applications such as gas sensor [3$5]$, biosensor [6,7], fuel cell catalyst [8,9], electrochemical sensor [10], electrocatalyst [11], and supercapacitor [12, 13]. When metal ions are added into the synthesized system of polyaniline, the metal ions can interact with the nitrogen atoms in the polyaniline chains [14]. Silver and copper have been proposed as alternate conductive filler in electrically conductive polymer composites for sensor applications, due 
to its high electrical conductivity, low electrical migration, and high compatibility.

Electrochemical impedance spectroscopy and the method of impedance are widely used for corrosion, batteries, bioelectrochemistry, and electrochemistry. EIS provide electrochemical examination of electrical properties of electrode surface; on the other hand, it can be called electrochemical surface characterization. Therefore it is possible to realize the differentiation of electrode surface alterations easily. In biosensor technology, it is used for monitoring biosensor modifications, layer formation on electrode surface, and binding kinetics between molecules such as DNAs [15], antibodies [16], proteins [17, 18], carbohydrate [19], glucose [20], and virus [21]. In microbial sensor technology, there are some previous studies that conducted the EIS for E. coli bacteria detection [22-24].

In this paper, we reported the synthesis of $\mathrm{Ag}$-Cu doped polyaniline nanocomposite thin films to be applied as a biosensor to detect the presence of E. coli bacteria in water. Impedance analysis was used in conducting the sensing performance by observing the change in impedance after incubating the sensor electrode into E. coli.

\section{Experimental Methods}

Silver nitrate $\left(\mathrm{AgNO}_{3}, 99.99 \%\right.$ purity), copper acetate $\left(\mathrm{Cu}\left(\mathrm{CH}_{3} \mathrm{COO}\right)_{2}, 97 \%\right)$, aniline monomer $\left(\mathrm{C}_{6} \mathrm{H}_{5} \mathrm{NH}_{2}\right)$, and polyvinyl alcohol (PVA, 99\% hydrolysis and molar weight 85,000-124,000 g/mol) were purchased from Sigma-Aldrich Chemicals. In this study, the nanocomposite of polyaniline (PANI) and metals was prepared by the oxidative polymerization of aniline and the reduction process of metal compound with the presence of nitric acid and PVA. $2.5 \mathrm{~g}$ of PVA was completely dissolved in $40 \mathrm{~mL}$ deionized water and stirred on the hot plate at $80^{\circ} \mathrm{C}-90^{\circ} \mathrm{C}$. $0.5 \mathrm{~g}$ of silver nitrate and copper acetate was dissolved in deionized water and was added drop by drop into PVA solution by using pipette. Magnetic stirring continued until the solution become a brownish yellow viscous liquid. $1.25 \mathrm{~mL}$ of aniline was added to the solution followed by $1.0 \mathrm{M}$ nitric acid $\left(\mathrm{HNO}_{3}\right)$. The mixture was stirred until the solution changed to a greenish dark brown liquid, indicating that the solution became PANI$\mathrm{Ag}-\mathrm{Cu}$ nanocomposite. The nanocomposite solution was spin-coated on glass substrate using Laurell Technologies Corporation photoresist spinner, with the speed of $3000 \mathrm{rpm}$ for $30 \mathrm{~s}$. A comb structure of silver electrode was sputtered on the nanocomposite thin film for $1000 \AA$ thickness. Copper wires were soldered to the silver electrodes as the connection between thin film and the measuring device. X-ray diffraction (XRD) analysis was conducted on Bruker model D8 advanced X-ray diffractometer using $\mathrm{CuK} \alpha$ radiation $(\lambda=$ $1.5406 \AA$ ) and the measurement was performed in $2 \theta$ range from $20^{\circ}$ to $60^{\circ}$. The optical characterization of PANI-Ag$\mathrm{Cu}$ nanocomposite thin films was carried out using Perkin Elmer UV-Visible spectroscopy. Fourier transform infrared (FTIR) spectroscopy was used to determine the vibrational stretch frequency of polymer-metals bonds. Electrochemical impedance analysis of the thin films was conducted using

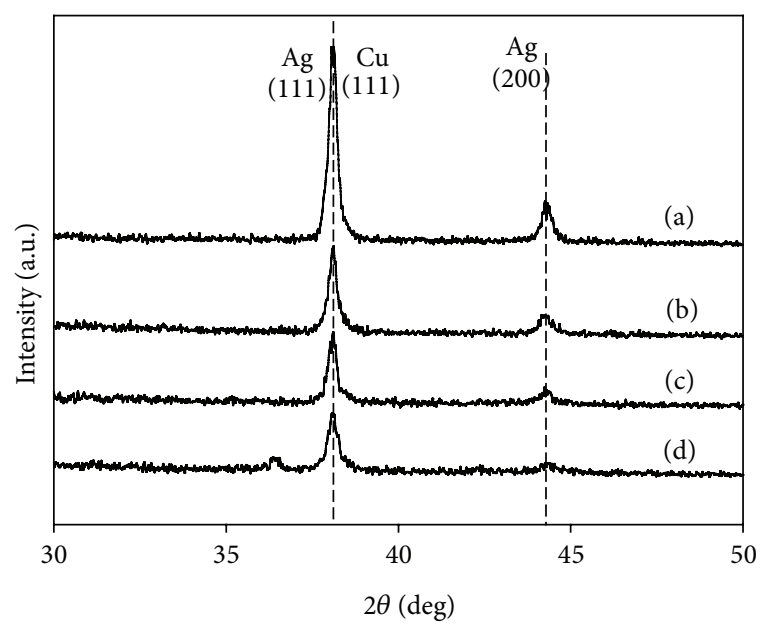

FIgURE 1: XRD spectra of PANI-Ag-Cu nanocomposite thin films with the concentration ratios of $\mathrm{Ag}-\mathrm{Cu}$; (a) $\mathrm{Ag}_{0.85}-\mathrm{Cu}_{0.15}$, (b) $\mathrm{Ag}_{0.65}{ }^{-}$ $\mathrm{Cu}_{0.35}$, (c) $\mathrm{Ag}_{0.45}-\mathrm{Cu}_{0.55}$, and (d) $\mathrm{Ag}_{0.25}-\mathrm{Cu}_{0.75}$.

TABLE 1: Calculated crystallite size of PANI-Ag-Cu nanocomposite thin films.

\begin{tabular}{|c|c|c|}
\hline \multicolumn{2}{|c|}{ Concentration (\%) } & \multirow{2}{*}{ Crystallite size (nm) } \\
\hline Ag & $\mathrm{Cu}$ & \\
\hline 0.85 & 0.15 & 19.8 \\
\hline 0.65 & 0.35 & 19.4 \\
\hline 0.45 & 0.55 & 19.0 \\
\hline 0.25 & 0.75 & 18.7 \\
\hline
\end{tabular}

GAMRY-Physical Electrochemistry to test the sensitivity of PANI-Ag-Cu thin films towards E. coli bacteria.

\section{Results and Discussions}

3.1. X-Ray Diffraction (XRD) Analysis. The X-ray diffraction patterns of PANI-Ag-Cu nanocomposite thin films were shown in Figure 1. The narrow peaks indicate the high degree of crystallinity of $\mathrm{Ag}$ and $\mathrm{Cu}$ in face-centered cubic (FCC) structure. The prominent peaks at $38.1^{\circ}$ and $44.3^{\circ}$ of Bragg's reflections represent the (111) and (200) lattice plane of FCC structure of silver, while the FCC structure of copper shares the same lattice plane at (111). The increase in Ag concentration also increases the degree of crystallinity. The average crystallite sizes were calculated using Scherrer's equation [25]:

$$
D=\frac{0.9 \lambda}{\beta \cos \theta},
$$

where $\lambda=0.154 \mathrm{~nm}$ is the wavelength of $\mathrm{X}$-ray for $\mathrm{CuK} \alpha, \beta$ is FWHM (full width at half maximum intensity of the peak), $\theta$ is the diffraction angle, and $D$ is the crystallite size. The values of the calculated crystallite size have been summarized in Table 1 . The size of crystallite is directly proportional to the concentration of $\mathrm{Ag}$ but inversely proportional to the concentration of $\mathrm{Cu}$. The concentration of Ag influenced the size of crystallite in the nanocomposite thin film due to the atomic radius of $\mathrm{Ag}$ which is larger than $\mathrm{Cu}$. 


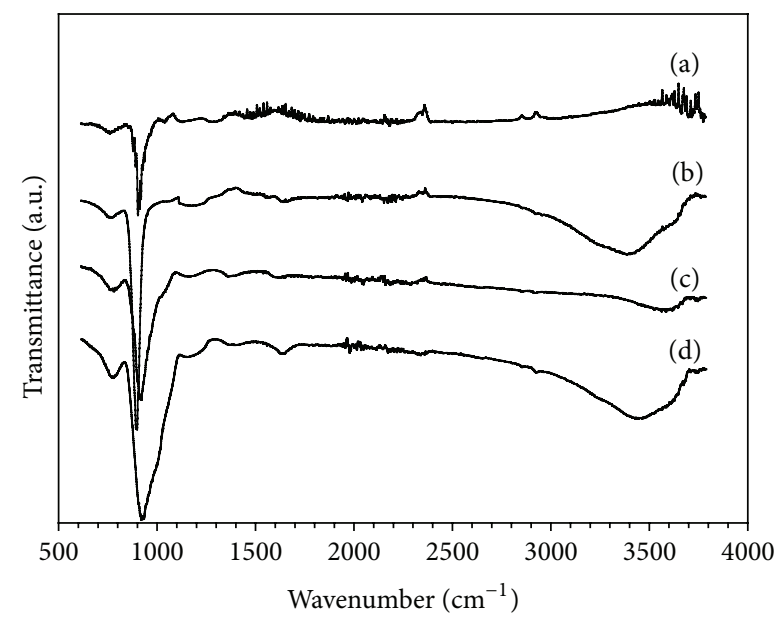

FIgURE 2: FTIR spectra of PANI-Ag-Cu nanocomposite thin films with various concentrations of Ag-Cu; (a) $\mathrm{Ag}_{0.85}-\mathrm{Cu}_{0.15}$, (b) $\mathrm{Ag}_{0.65}$ $\mathrm{Cu}_{0.35}$, (c) $\mathrm{Ag}_{0.45}-\mathrm{Cu}_{0.55}$, and (d) $\mathrm{Ag}_{0.25}-\mathrm{Cu}_{0.75}$.

3.2. Fourier Transform Infrared (FTIR). Figure 2 shows the FTIR spectra of PANI-Ag-Cu nanocomposite thin films. The bands in the region $3400-3600 \mathrm{~cm}^{-1}$ normally attributed to the protonation of amines functional group at polyaniline backbone (N-H stretching) [26]. The bands corresponding to quinonoid $(\mathrm{N}=\mathrm{Q}=\mathrm{N})$ and benzenoid $(\mathrm{N}-\mathrm{B}-\mathrm{N})$ ring stretching modes of PANI were observed at 1508 and $1590 \mathrm{~cm}^{-1}$, respectively. The evidence of formation of polyaniline with 1,4 -subtituted phenyl rings occurred at around $880 \mathrm{~cm}^{-1}$ [27]. This product is composed of nonconducting aniline oligomers containing phenazine-like units and conducting PANI.

3.3. UV-Visible Spectroscopy. UV-Vis absorption is performed to verify the presence of silver and copper nanoparticles in the prepared samples of PANI-Ag-Cu nanocomposite thin films as shown in Figure 3. Those spectra contain maximum absorption band at $475 \mathrm{~nm}, 475 \mathrm{~nm}, 474 \mathrm{~nm}$, and $473 \mathrm{~nm}$ in Figures 3(a), 3(b), 3(c), and 3(d), respectively, which confirmed the presence of silver and copper nanoparticles [28]. In Figure 3(d), the peak for sample PANI-Ag ${ }_{0.25}-\mathrm{Cu}_{0.75}$ is not seen in the spectrum because the maximum absorption intensity for this sample is too small. In Figure 3(a), sample PANI- $\mathrm{Ag}_{0.85}-\mathrm{Cu}_{0.15}$ has the highest absorption intensity. It was found that the higher absorption intensity reflects the formation of more nanoparticles. The absorption peaks shift to the longer wavelength which indicates that the size of particle becomes larger. This is because the larger particles require lesser energy and, hence, longer wavelength [29]. So, sample PANI- $\mathrm{Ag}_{0.85}-\mathrm{Cu}_{0.15}$ in Figure 3(a) has larger particle size compared to the others.

3.4. Atomic Force Microscopy (AFM). AFM images in Figure 4 show the morphology of PANI-Ag-Cu nanocomposite thin films surface with different concentrations of $\mathrm{Ag}-\mathrm{Cu}$.

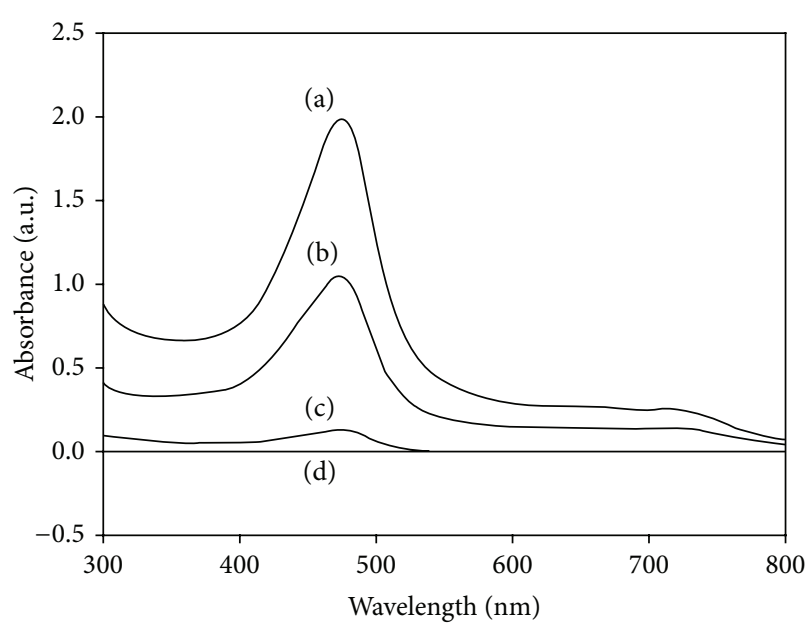

FIgURE 3: Absorption spectra of PANI-Ag-Cu nanocomposite thin films with various concentrations of $\mathrm{Ag}-\mathrm{Cu}$; (a) $\mathrm{Ag}_{0.85}-\mathrm{Cu}_{0.15}$, (b) $\mathrm{Ag}_{0.65}-\mathrm{Cu}_{0.35}$, (c) $\mathrm{Ag}_{0.45}-\mathrm{Cu}_{0.55}$, and (d) $\mathrm{Ag}_{0.25}-\mathrm{Cu}_{0.75}$.

TABLE 2: Average roughness and grain size of PANI-Ag-Cu nanocomposite thin films.

\begin{tabular}{lccc}
\hline \multicolumn{2}{l}{ Concentration $(\%)$} & Average roughness $(\mathrm{nm})$ & Grain size $(\mu \mathrm{m})$ \\
$\mathrm{Ag}$ & $\mathrm{Cu}$ & 2.761 & 0.0531 \\
0.85 & 0.15 & 1.498 & 0.0577 \\
0.65 & 0.35 & 1.331 & 0.0572 \\
0.45 & 0.55 & 4.800 & 0.0302 \\
0.25 & 0.75 & & \\
\hline
\end{tabular}

The average surface roughness and grain size were being listed in Table 2. As the Ag concentration decreased and $\mathrm{Cu}$ concentration increased, both surface roughness and grain sizes are found to be decreased. The surface roughness and grain size are proportional to the concentration of Ag because the thin film surface becomes smooth when the majority of the atoms are having small atomic radius [30]. The atomic radius of $\mathrm{Ag}$ is larger than $\mathrm{Cu}$.

3.5. Field Emission Scanning Electron Microscopy (FESEM). The morphology of prepared PANI-Ag-Cu nanocomposites was determined by FESEM image with low and high magnification as shown in Figure 5. The image shows the silver and copper particles synthesized by reduction of silver ions using nitric acid resembling nanospherical with average diameter of about $\sim 5-20 \mathrm{~nm}$. At the magnification of 20000x and 30000x in Figures 5(a) and 5(b), the images clearly show nonagglomerated uniformly distributed silver and copper nanoparticles as reported by Khanna et al. [31, 32]. Figure 5(c) shows the image at magnification of 50000x, silver and copper nanoparticles agglomerated in PANI matrix. The thickness of PANI-Ag-Cu thin film cross sectional is determined about $250 \mathrm{~nm}$ as shown in Figure 5(d). 


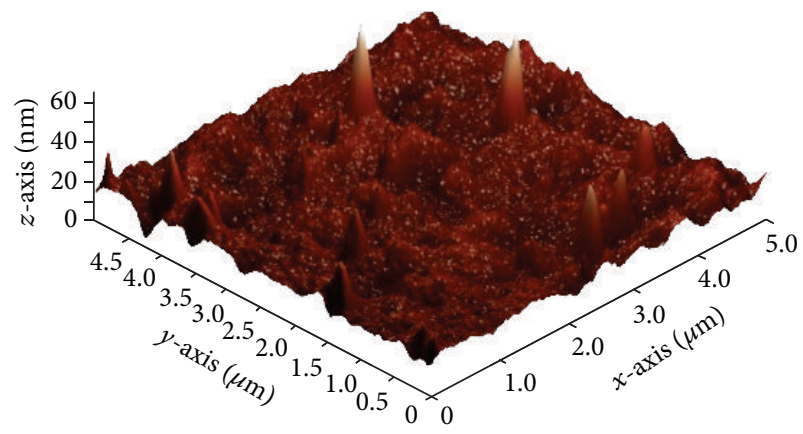

(a)

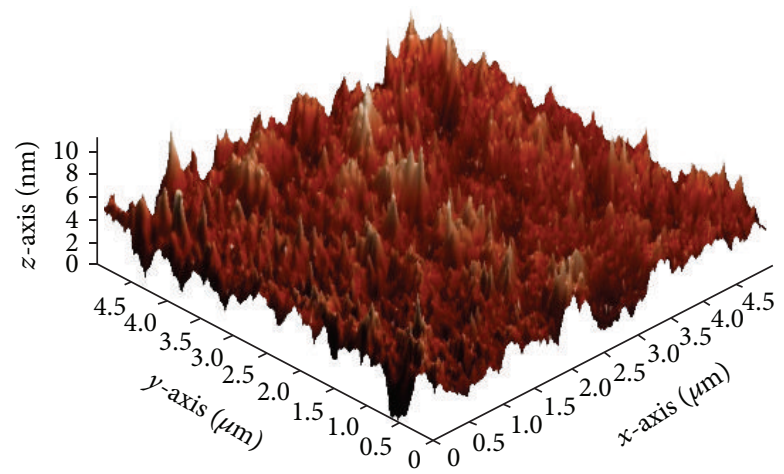

(c)

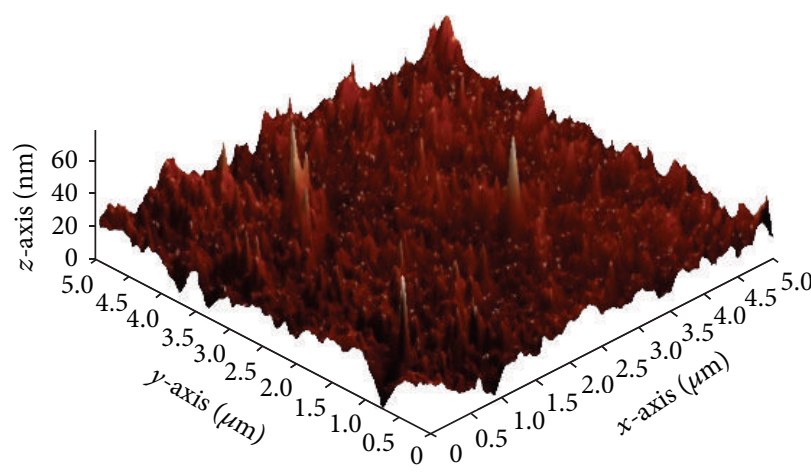

(b)

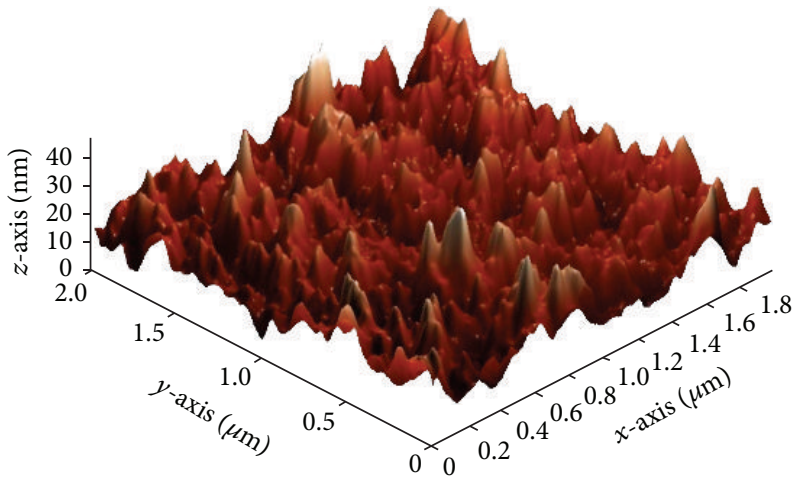

(d)

Figure 4: AFM images of PANI-Ag-Cu nanocomposite thin films with various concentrations of $\mathrm{Ag}-\mathrm{Cu}$; (a) $\mathrm{Ag}_{0.85}-\mathrm{Cu}_{0.15},(\mathrm{~b}) \mathrm{Ag}_{0.65}-\mathrm{Cu}_{0.35}$, (c) $\mathrm{Ag}_{0.45}-\mathrm{Cu}_{0.55}$, and (d) $\mathrm{Ag}_{0.25}-\mathrm{Cu}_{0.75}$.

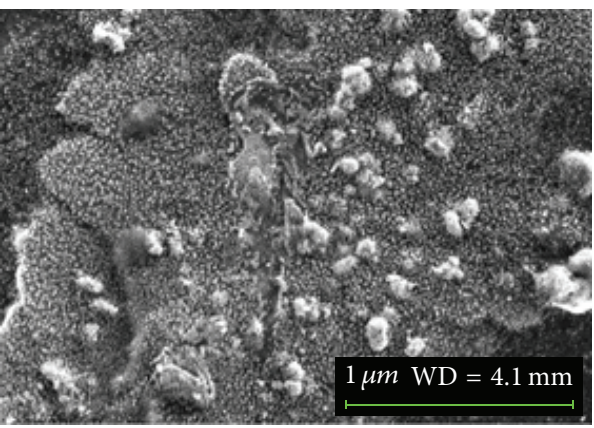

(a)

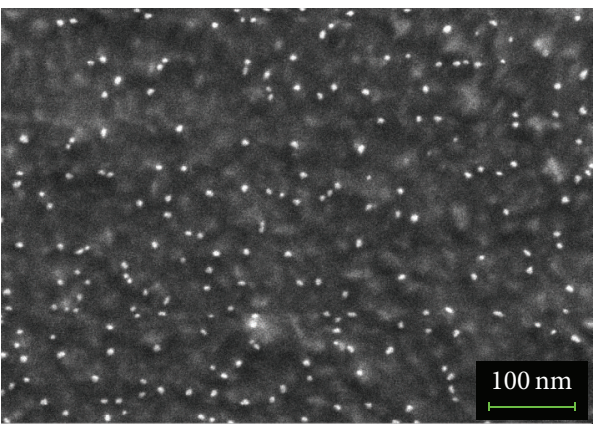

(c)

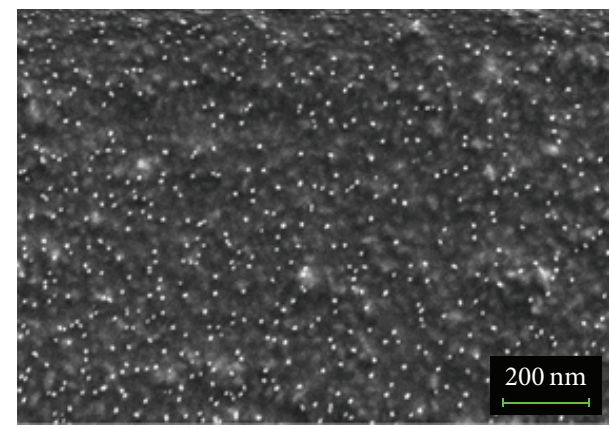

(b)

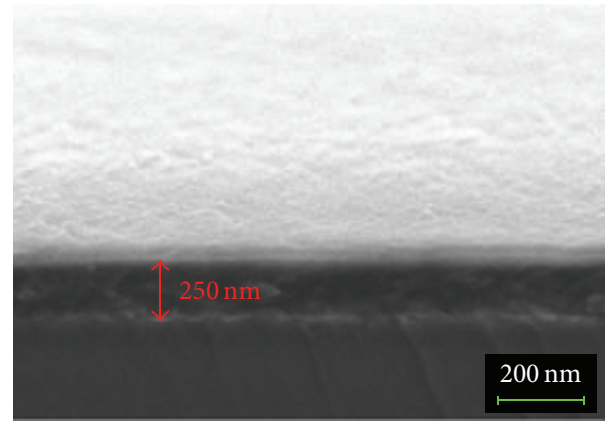

(d)

Figure 5: FESEM images of prepared PANI-Ag $0.45-\mathrm{Cu}_{0.55}$ nanocomposite at magnification of (a) $20 \mathrm{kx}$, (b) $30 \mathrm{kx}$, (c) $50 \mathrm{kx}$, and (d) the crosssectional thickness. 


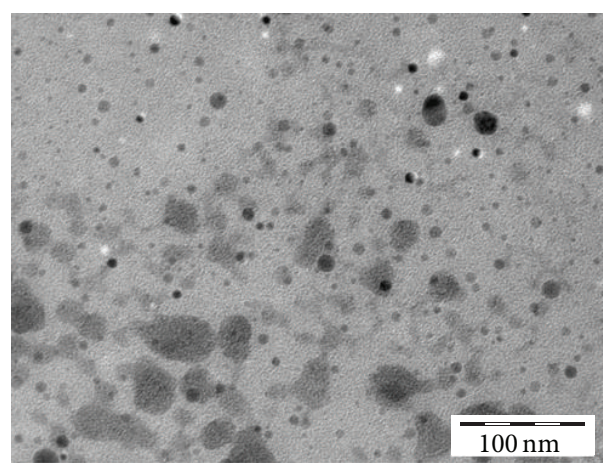

FIgURE 6: TEM images of PANI- $\mathrm{Ag}_{0.2}-\mathrm{Cu}_{0.8}$ nanocomposite.

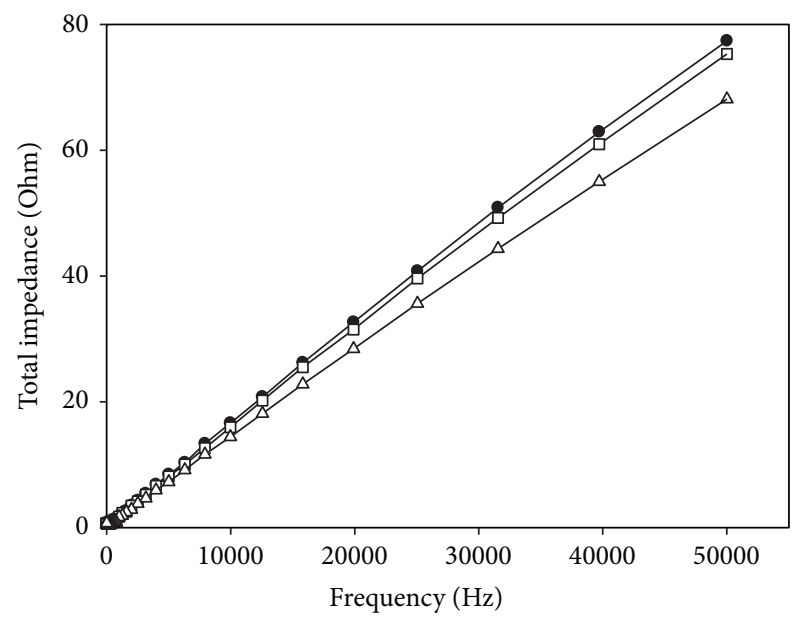

(a)

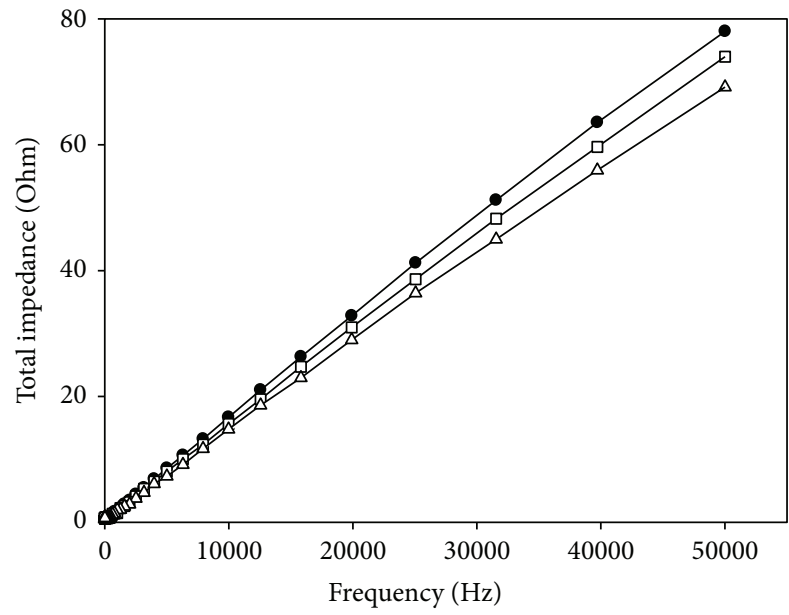

$\rightarrow$ Air
$\rightarrow$ Water
$\triangle$ E. coli

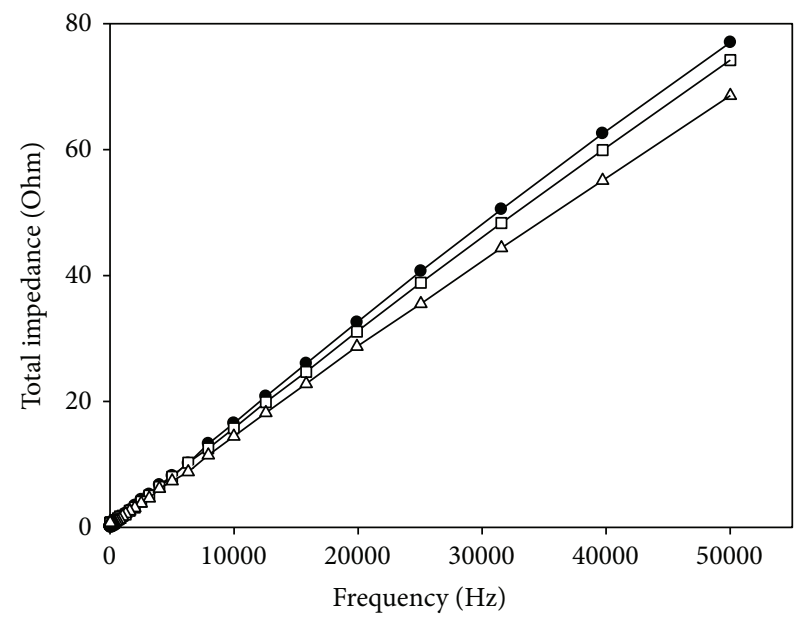

(b)

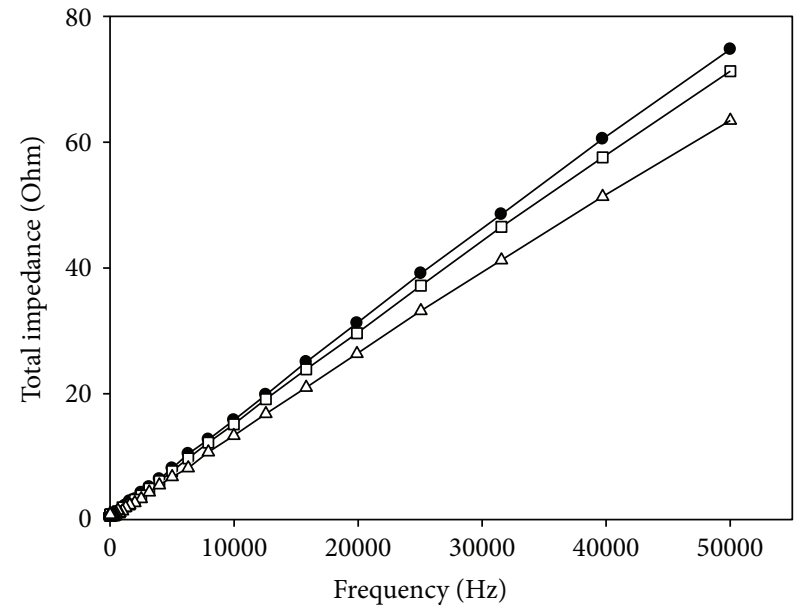

$\rightarrow$ Air
$\rightarrow$ Water
$\triangle$ E. coli

(c)

(d)

FIGURE 7: Total impedance versus frequency plots in different conditions exposed only to air, immersed in deionized water, and incubated in E. coli for PANI-Ag-Cu nanocomposite thin films with various concentrations of $\mathrm{Ag}$-Cu; (a) $\mathrm{Ag}_{0.85}-\mathrm{Cu}_{0.15}$, (b) $\mathrm{Ag}_{0.65}-\mathrm{Cu}_{0.35}$, (c) $\mathrm{Ag}_{0.45}-\mathrm{Cu}_{0.55}$, and (d) $\mathrm{Ag}_{0.25}-\mathrm{Cu}_{0.75}$. 
3.6. Transmittance Electron Microscopy (TEM). TEM microphotograph in Figure 6 shows the particle morphologies of PANI-Ag-Cu nanocomposite. The nanoparticles of silver and copper are mostly spherical in shape with the particle diameter size in the range from $\sim 6 \mathrm{~nm}$ to $\sim 14 \mathrm{~nm}$. Some particles are agglomerated and encapsulated in the polymer matrix. As reported by Singh et al., the morphology of Ag$\mathrm{Cu}$ nanoparticles encapsulated by starch polymer is mostly spherical and faceted features appear for aggregates only [33].

3.7. Sensor Performance. The sensing study was done with different conditions of sensor thin films as shown in Figure 7 which were exposed only to air, immersed in deionized water, and incubated in E. coli solution. The concentrations of $E$. coli in the solution were fixed to $10^{8} \mathrm{CFU} / \mathrm{mL}$ for each testing. We used the higher concentration of E. coli compared to the previous study done by another researcher $[23,24]$ to obtain the optimum performance on sensitivity. We investigated the effect of different concentrations of $\mathrm{Ag}$ and $\mathrm{Cu}$ on impedance signal. It was found that the impedance value became lower when the sensor films were immersed in water after being exposed to air. It indicates that the current flow on the sensor films surface is more conductive in deionized water. When the sensor films incubated in E. coli solution, the impedance decreases to lower value. The decreasing in impedance represents the increasing in current flow on the sensor films. The current flow is higher in the E. coli solution and this proves the existence of reactions between metal and microbe. When the sensor films are immersed into water with E. coli, the silver ions and copper ions on the PANI-Ag$\mathrm{Cu}$ thin film surface interact with the microbe. The positive charge of $\mathrm{Ag}^{+}$and $\mathrm{Cu}^{2+}$ could be attached to the negatively charged E. coli [34]. The metabolism of the microbe creates an acid environment for the release of metal ions and it is believed that the silver and copper ions interact with bacterial cell walls, plasma membranes, bacterial DNA, and proteins, as well as ribosomes, resulting in bactericidal effects [35]. The metal and microbe interactions are mainly related to the cell wall and outer membrane arrangement. This is due to the significant differences in the outer layers of Gram-negative and Gram-positive bacteria. The cell wall of Gram-negative bacteria consists of lipids, protein, and lipopolysaccharides (LPS) that ensure more effective defense against biocides in comparison to Gram-positive bacteria where the cell wall does not contain outer membrane of LPS [36]. Since E. coli are Gram-negative bacteria, they possess an outer membrane and a unique periplamic space [37], thus E. coli are more susceptible to metal nanoparticles.

The sensitivity of the sensor is described as the ratio of the magnitude of response upon exposure to the microbe $\left(Z_{e}\right)$ to that of without exposure to the microbe $\left(Z_{o}\right)$. Figure 8 shows the graph of sensitivity $(S)$ on $E$. coli against the concentration ratios of $\mathrm{Cu}$ which is calculated using the formula [24]:

$$
S=\frac{Z_{o}-Z_{e}}{Z_{o}} \times 100,
$$

where $Z_{o}$ is the impedance of sensor in water and $Z_{e}$ is the impedance after introducing $E$. coli in water. Regarding

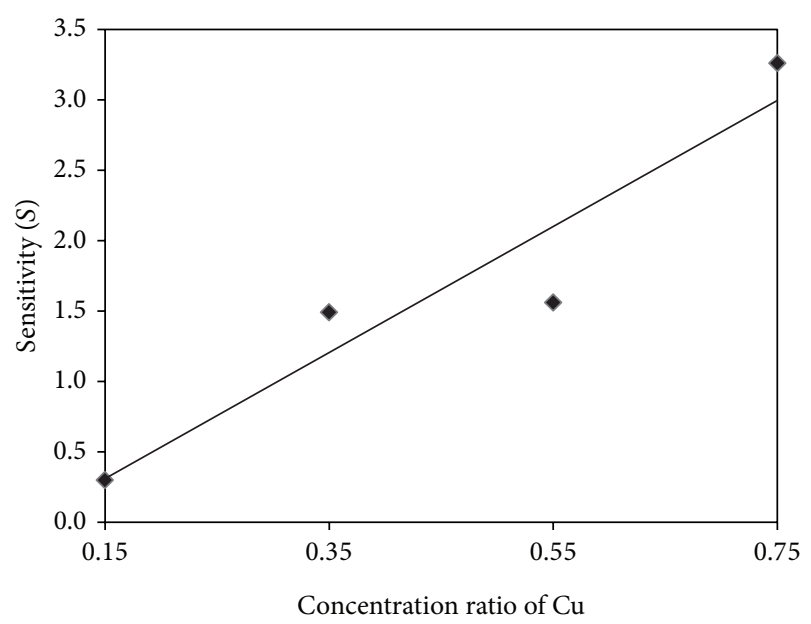

Figure 8: Sensitivity $(S)$ towards E. coli for PANI-Ag-Cu nanocomposite thin films with concentration ratios of $\mathrm{Cu}$.

Figure 8, the sensitivity increased with the increasing of concentration ratios of $\mathrm{Cu}$. The samples of PANI-Ag ${ }_{0.25^{-}}$ $\mathrm{Cu}_{0.75}$ performed the highest percentage of sensitivity which is $3.3 \%$, while PANI- $\mathrm{Ag}_{0.85}-\mathrm{Cu}_{0.15}$ only performed $0.3 \%$ of sensitivity towards $E$. coli. It indicates that $\mathrm{Cu}^{2+}$ makes more interaction with the microbe compared to $\mathrm{Ag}^{+}$. When $\mathrm{Cu}^{2+}$ dissolve in water, they are oxidized immediately to form $\mathrm{Cu}^{2+}$ ions. Electrically charged $\mathrm{Cu}^{2+}$ in the water search for particles of opposite polarity which are E. coli bacteria. Positive charge of copper ions forms electrostatic compound with negatively charged cell walls of microorganisms. This enhances the current flow on the sensor films thus decreasing the impedance.

\section{Conclusion}

In conclusion, PANI-Ag-Cu nanocomposite thin films were synthesized by chemical oxidative polymerization of aniline monomer to be applied as E. coli contamination sensor. Ag$\mathrm{Cu}$ concentrations are varied to find the optimum concentration to detect microorganisms. XRD analysis indicates the formation of the single crystal Ag and Cu crystals laid on (111) lattice planes. The crystallite sizes decrease as the Ag concentration decreases and $\mathrm{Cu}$ concentration increases. FTIR spectra show the bonding of $\mathrm{N}-\mathrm{H}$ in polyaniline structure. $\mathrm{UV}-\mathrm{Vis}$ absorption spectra confirmed the formation of $\mathrm{Ag}$ and $\mathrm{Cu}$ nanoparticles in the PANI matrix and the resonance plasmon band located at around 470 to $475 \mathrm{~nm}$. The performance of sensor has been conducted using impedance spectroscopy analysis in air, deionized water, and E. coli solution. The change in impedance when the sensor electrode incubated in $E$. coli proves the existence of reactions between metal and microbe. The result shows that PANI-Ag $\mathrm{A}_{0.25}-\mathrm{Cu}_{0.75}$ nanocomposite thin film performed the highest sensitivity among the other samples. It indicates that the reduction of Ag concentration and increment of $\mathrm{Cu}$ concentration developed the sensitivity of the sensor electrode on E. coli. 


\section{Conflict of Interests}

The authors declare that there is no conflict of interests regarding the publication of this paper.

\section{Acknowledgments}

This project was supported by Exploratory Research Grants Scheme (ERGS/1/2012/STG05/UKM/02/5), Islamic Educational, Scientific and Cultural Organization (ISESCO) (KK2013-006), and Photonic Technology Laboratory, Department of Electrical, Electronic and System Engineering, University Kebangsaan Malaysia, Bangi, Selangor, Malaysia.

\section{References}

[1] S. M. Reda and S. M. Al-Ghannam, "Synthesis and electrical properties of polyaniline composite with silver nanoparticles," Advances in Materials Physics and Chemistry, vol. 2, pp. 75-81, 2012.

[2] G. B. V. S. Lakshmi, M. Alam, A. M. Siddiqui, M. Zulfequar, and M. Husain, "Synthesis and characterization of Se doped polyaniline," Current Applied Physics, vol. 11, no. 2, pp. 217-222, 2011.

[3] S. C. K. Misra, P. Mathur, M. Yadav, M. K. Tiwari, S. C. Garg, and P. Tripathi, "Preparation and characterization of vacuum deposited semiconducting nanocrystalline polymeric thin film sensors for detection of HCl," Polymer, vol. 45, no. 25, pp. 8623$8628,2004$.

[4] S. C. K. Misra, P. Mathur, and B. K. Srivastava, "Vacuum-deposited nanocrystalline polyaniline thin film sensors for detection of carbon monoxide," Sensors and Actuators A, vol. 114, no. 1, pp. 30-35, 2004.

[5] A. Choudhury, "Polyaniline/silver nanocomposites: dielectric properties and ethanol vapour sensitivity," Sensors and Actuators B, vol. 138, no. 1, pp. 318-325, 2009.

[6] X. Feng, R. Li, Y. Ma, Q. Fan, and W. Huang, "The synthesis of highly electroactive $\mathrm{N}$-doped carbon nanotube/polyaniline/ $\mathrm{Au}$ nanocomposites and their application to the biosensor," Synthetic Metals, vol. 161, no. 17-18, pp. 1940-1945, 2011.

[7] X. Chen, Z. Chen, J. Zhu, C. Xu, W. Yan, and C. Yao, "A novel $\mathrm{H}_{2} \mathrm{O}_{2}$ amperometric biosensor based on gold nanoparticles/self-doped polyaniline nanofibers," Bioelectrochemistry, vol. 82, no. 2, pp. 87-94, 2011.

[8] B. Lai, P. Wang, H. Li, Z. Du, L. Wang, and S. Bi, "Calcined polyaniline-iron composite as a high efficient cathodic catalyst in microbial fuel cells," Bioresource Technology, vol. 131, pp. 321324, 2013.

[9] Z. Mo, H. Peng, H. Liang, and S. Liao, "Vesicular nitrogen doped carbon material derived from $\mathrm{Fe}_{2} \mathrm{O}_{3}$ templated polyaniline as improved non-platinum fuel cell cathode catalyst," Electrochimica Acta, vol. 99, pp. 30-37, 2013.

[10] K.-J. Huang, J.-Z. Zhang, Y.-J. Liu, and L.-L. Wang, "Novel electrochemical sensing platform based on molybdenum disulfide nanosheets-polyaniline composites and Au nanoparticles," Sensors and Actuators B, vol. 194, pp. 303-310, 2014.

[11] Z.-S. Yin, T.-H. Hu, J.-L. Wang, C. Wang, Z.-X. Liu, and J.W. Guo, "Preparation of highly active and stable polyanilinecobalt-carbon nanotube electrocatalyst for oxygen reduction reaction in polymer electrolyte membrane fuel cell," Electrochimica Acta, vol. 119, pp. 144-154, 2014.
[12] H. Xu, J. Li, Z. Peng, J. Zhuang, and J. Zhang, "Investigation of polyaniline films doped with $\mathrm{Ni}^{2+}$ as the electrode material for electrochemical supercapacitors," Electrochimica Acta, vol. 90, pp. 393-399, 2013.

[13] S. Giri, D. Ghosh, and C. K. Das, "In situ synthesis of cobalt doped polyaniline modified graphene composites for high performance supercapacitor electrode materials," Journal of Electroanalytical Chemistry, vol. 697, pp. 32-45, 2013.

[14] Y. Tan, Y. Zhang, and J. Kan, "Synthesis and properties on polyaniline in the presence of nickel chloride," Express Polymer Letters, vol. 3, no. 6, pp. 333-339, 2009.

[15] K.-J. Huang, Y.-J. Liu, H.-B. Wang, and Y.-Y. Wang, "A sensitive electrochemical DNA biosensor based on silver nanoparticlespolydopamine@graphene composite,"Electrochimica Acta, vol. 118, pp. 130-137, 2014.

[16] H. B. Fredj, S. Helali, C. Esseghaier, L. Vonna, L. Vidal, and A. Abdelghani, "Labeled magnetic nanoparticles assembly on polypyrrole film for biosensor applications," Talanta, vol. 75, no. 3, pp. 740-747, 2008.

[17] J. A. Lee, S. Hwang, J. Kwak, S. I. Park, S. S. Lee, and K.-C. Lee, "An electrochemical impedance biosensor with aptamermodified pyrolyzed carbon electrode for label-free protein detection," Sensors and Actuators, B: Chemical, vol. 129, no. 1, pp. 372-379, 2008.

[18] X. Li, L. Shen, D. Zhang et al., "Electrochemical impedance spectroscopy for study of aptamer-thrombin interfacial interactions," Biosensors and Bioelectronics, vol. 23, no. 11, pp. 1624$1630,2008$.

[19] Y. Hu, P. Zuo, and B.-C. Ye, "Label-free electrochemical impedance spectroscopy biosensor for direct detection of cancer cells based on the interaction between carbohydrate and lectin," Biosensors and Bioelectronics, vol. 43, no. 1, pp. 79-83, 2013.

[20] R. K. Shervedani, A. H. Mehrjardi, and N. Zamiri, "A novel method for glucose determination based on electrochemical impedance spectroscopy using glucose oxidase self-assembled biosensor," Bioelectrochemistry, vol. 69, no. 2, pp. 201-208, 2006.

[21] B. T. T. Nguyen, A. E. K. Peh, C. Y. L. Chee et al., "Electrochemical impedance spectroscopy characterization of nanoporous alumina dengue virus biosensor," Bioelectrochemistry, vol. 88, pp. 15-21, 2012.

[22] C. Ruan, L. Yang, and Y. Li, "Immunobiosensor chips for detection of Escherichia coli O157:H7 using electrochemical impedance spectroscopy," Analytical Chemistry, vol. 74, no. 18, pp. 4814-4820, 2002.

[23] A. D. Chowdhury, A. De, C. R. Chaudhuri, K. Bandyopadhyay, and P. Sen, "Label free polyaniline based impedimetric biosensor for detection of E. coli O157:H7 Bacteria," Sensors and Actuators B: Chemical, vol. 171-172, pp. 916-923, 2012.

[24] P. K. Basu, D. Indukuri, S. Keshavan et al., "Graphene based E. coli sensor on flexible acetate sheet," Sensors and Actuators B: Chemical, vol. 190, pp. 342-347, 2014.

[25] I. Saini, J. Rozra, N. Chandak, S. Aggarwal, P. K. Sharma, and A. Sharma, "Tailoring of electrical, optical and structural properties of PVA by addition of Ag nanoparticles," Materials Chemistry and Physics, vol. 139, no. 2-3, pp. 802-810, 2013.

[26] M. Khairy and M. E. Gouda, "Electrical and optical properties of nickel ferrite/polyaniline nanocomposite," Journal of Advanced Research, 2014.

[27] Y. B. Wankhede, S. B. Kondawar, S. R. Thakare, and P. S. More, "Synthesis and characterization of silver nanoparticles 
embedded in polyaniline nanocomposite," Advanced Materials Letters, vol. 4, no. 1, pp. 89-93, 2013.

[28] L.-U. Rahman, R. Qureshi, M. M. Yasinzai, and A. Shah, "Synthesis and spectroscopic characterization of Ag-Cu alloy nanoparticles prepared in various ratios," Comptes Rendus Chimie, vol. 15, no. 6, pp. 533-538, 2012.

[29] R. P. Chauhan, "Colloidal synthesis of silver nano particles," Asian Journal of Chemistry, vol. 21, no. 10, pp. S113-S116, 2009.

[30] N. P. Ariyanto, H. Abdullah, and N. S. A. Ghani, "Surface morphology characterisation of Sn-doped $\mathrm{ZnO}$ films for antireflective coating," Materials Research Innovations, vol. 13, no. 3, pp. 157-160, 2009.

[31] P. K. Khanna, S. Gaikwad, P. V. Adhyapak, N. Singh, and R. Marimuthu, "Synthesis and characterization of copper nanoparticles," Materials Letters, vol. 61, no. 25, pp. 4711-4714, 2007.

[32] P. K. Khanna, N. Singh, S. Charan, V. V. V. S. Subbarao, R. Gokhale, and U. P. Mulik, "Synthesis and characterization of Ag/ PVA nanocomposite by chemical reduction method," Materials Chemistry and Physics, vol. 93, no. 1, pp. 117-121, 2005.

[33] M. Singh, I. Sinha, A. K. Singh, and R. K. Mandal, "LSPR and SAXS studies of starch stabilized Ag-Cu alloy nanoparticles," Colloids and Surfaces A: Physicochemical and Engineering Aspects, vol. 384, no. 1-3, pp. 668-674, 2011.

[34] H. Su, Q. Ma, K. Shang, T. Liu, H. Yin, and S. Ai, "Gold nanoparticles as colorimetric sensor: a case study on E. coli O157:H7 as a model for Gram-negative bacteria," Sensors and Actuators B: Chemical, vol. 161, no. 1, pp. 298-303, 2012.

[35] L. Guo, W. Yuan, Z. Lu, and C. M. Li, "Polymer/nanosilver composite coatings for antibacterial applications," Colloids and Surfaces A: Physicochemical and Engineering Aspects, vol. 439, pp. 69-83, 2013.

[36] R. Bryaskova, D. Pencheva, G. M. Kale, U. Lad, and T. Kantardjiev, "Synthesis, characterisation and antibacterial activity of PVA/TEOS/Ag-Np hybrid thin films," Journal of Colloid and Interface Science, vol. 349, no. 1, pp. 77-85, 2010.

[37] J. Díaz-Visurraga, C. Gutiérrez, C. von Plessing, and A. García, "Metal nanostructures as antibacterial agents," in Science and Technology Against Microbial Pathogens: Research, Development and Evaluation, pp. 210-218, Formatex, Badajoz, Spain, 2011. 

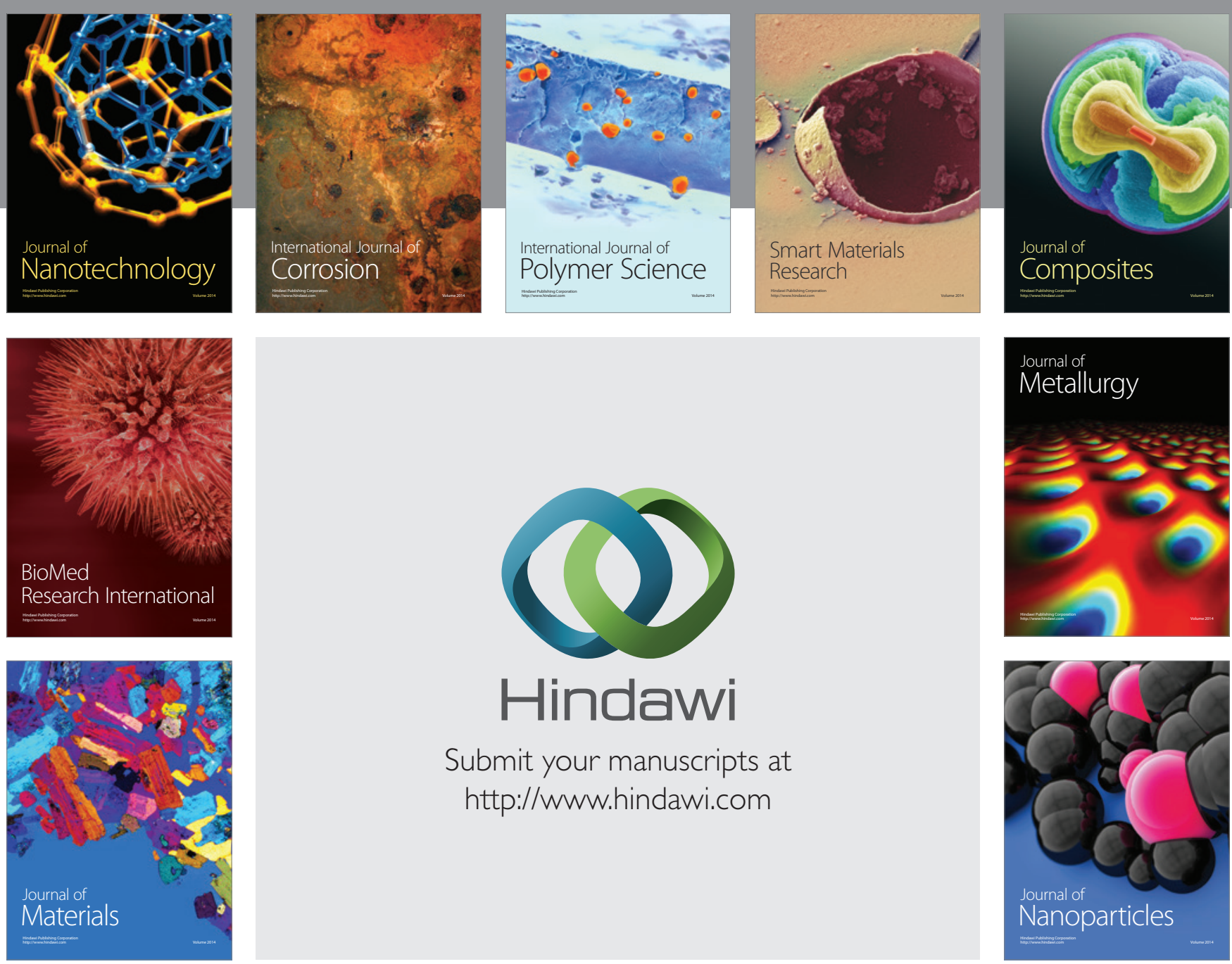

Submit your manuscripts at http://www.hindawi.com
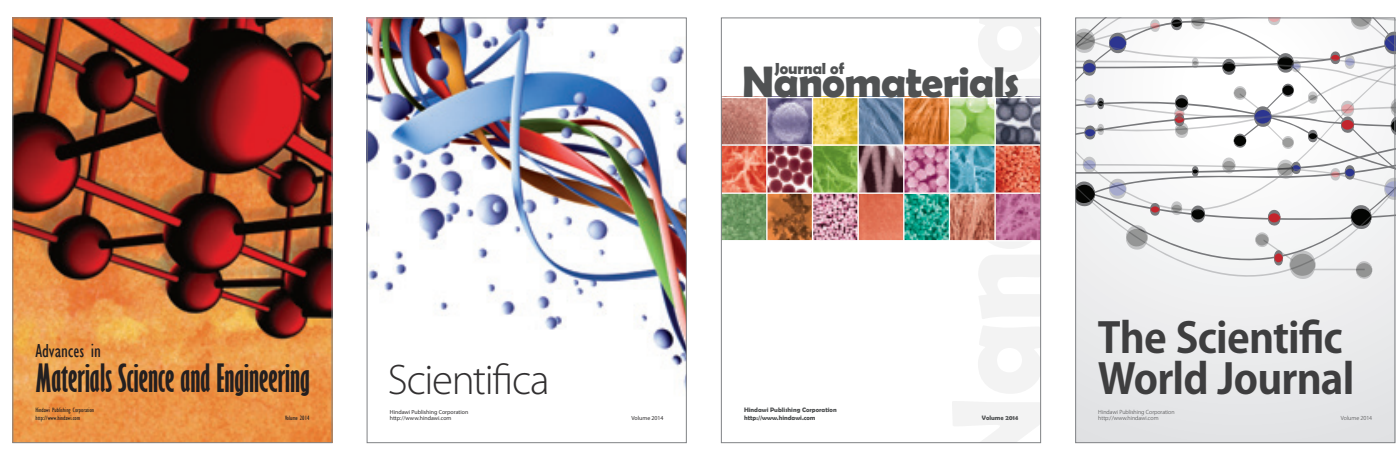

\section{The Scientific World Journal}
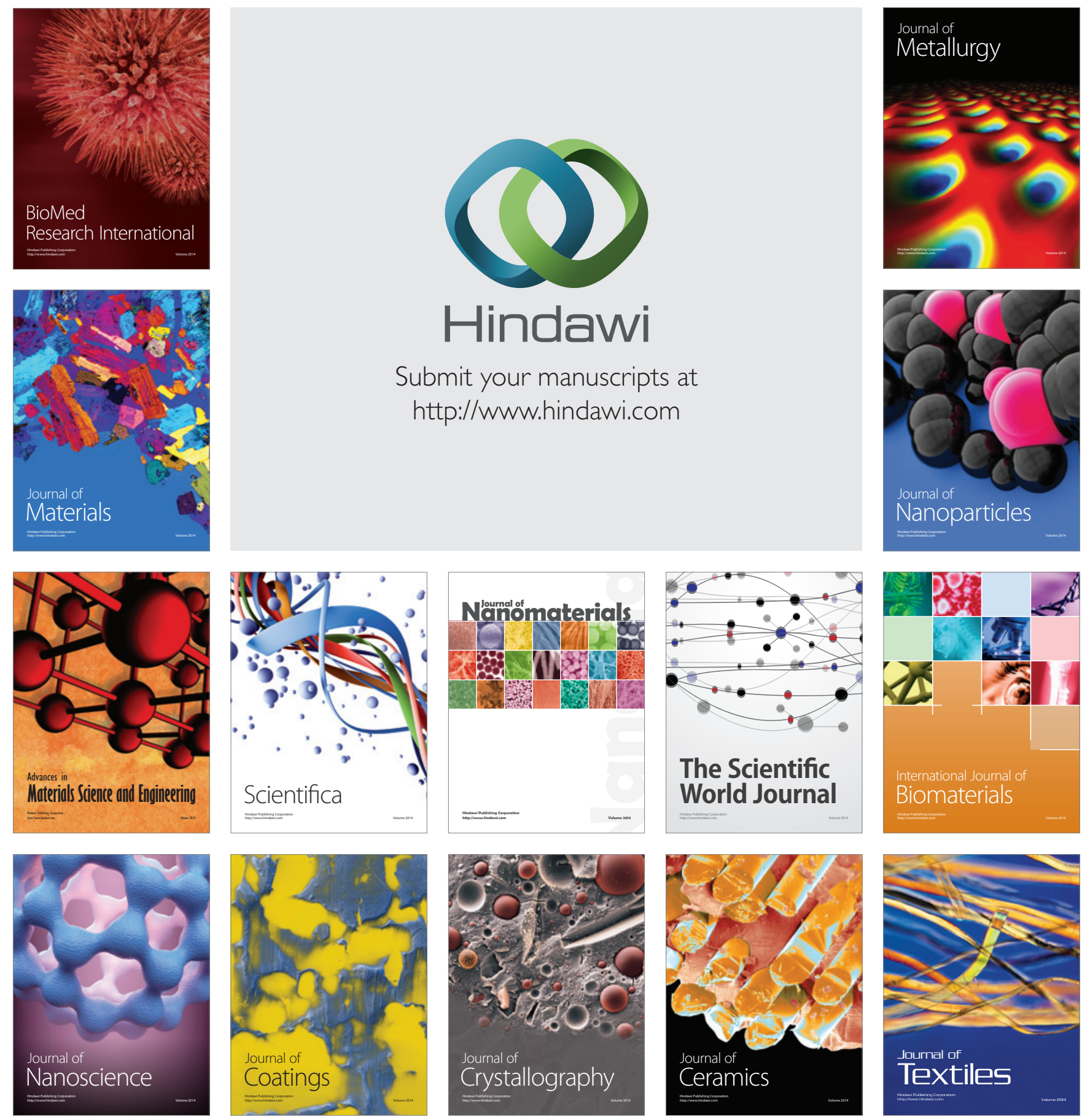